\title{
Capital from an Insurance Company
}

\section{Perspective}

Robert E. Lewis

This morning, I would like to give a few practical comments on capital adequacy from an insurance company perspective. In doing so, I will present two views on capital adequacy and capital allocation in the insurance industry. The first view is the regulatory perspective, that is, the motivations behind regulatory capital requirements in the insurance industry, the structure of those requirements, and the relationship between regulatory capital amounts and the actual risks facing insurance companies. The second view is an insurance company perspective, in particular, the approach taken by the American International Group (AIG) to determine adequate capital allocations for our various businesses and for the firm overall.

\section{Regulatory PERSPeCTIVE}

The regulatory perspective on capital adequacy was well summarized, in June 1996, by B.K. Atchinson, president of the National Association of Insurance Commissioners (NAIC):

The most important duty of insurance commissioners is to help maintain the financial stability of the insurance industry - that is, to guard against insolvencies... Among the greatest weapons against insolvency are the risk-based capital requirements.

Robert E. Lewis is chief credit officer at American International Group, Inc.
In other words, the NAIC recognizes the important role that capital can play in preventing insolvencies and has implemented a set of risk-based capital requirements intended to address this concern.

Without going into the details of the calculations, the NAIC's risk-based capital requirements are intended to capture several forms of risk facing insurance companies. For life/health companies, these risks include:

- asset risk: the risk of default or a decline in the market value of assets;

- insurance risk: the risk that claims exceed expectations;

- interest risk: the risk of loss from changes in interest rates; and

- business risk: various risks arising from business operations, including guarantee fund assessments for the eventuality that one insurance company fails and others have to stand by with capital to assume some of those losses.

For property/casualty companies, the risks covered by the capital calculations are different, because the business is quite different. In brief, the risk-based capital calculations are intended to cover:

- asset risk: the risk of default or a decline in the market value of assets;

- credit risk: the risk of loss from unrecoverable reinsurance and other receivables; 
- underwriting risk: the risk of loss from pricing and reserving inadequacies; and

- off-balance-sheet risk: the risk of loss from factors such as contingencies or high business growth rates.

While the regulatory capital requirements are intended to cover a wide range of the risks facing insurance companies, the rules have a number of shortcomings. From a technical perspective, the calculations impose overly harsh capital requirements along several dimensions. For one, the calculations do not include covariance adjustments within risk groups, so the benefits of diversification of risks are not fully recognized. Further, the requirements impose undue penalties on affiliated investments, ceded reinsurance, and adequate reserving, as well as on affiliated foreign insurers. The NAIC's risk-based capital rules also have a number of shortcomings from a practical or operational perspective. In particular, the requirements are applied only to insurance firms in the United States; there is no international acceptance of these requirements and, therefore, no level playing field with regard to capital regulation. Even within the United States, not all states apply the NAIC guidelines. Finally, since the requirements do not cover the full range of risks facing insurance firms, supervisors typically expect insurers to maintain multiples of the minimum risk-based capital requirement.

Further, in practice, the requirements have not proven to provide either a good predictor of future insolvency or a consistent rating of relative financial strength among insurers. History has shown that only a small percentage of insolvent insurers failed the risk-based capital test prior to their insolvency. Conversely, of those insurers that fail the risk-based capital test, only a small percentage actually become insolvent. Thus, the risk-based capital rules provide a very noisy indicator of the actual financial strength of U.S. insurance companies. On the plus side, however, the rules have permitted supervisors to take prompt regulatory steps against insurers without court action.

\section{INSURANCE COMPANY PERSPECTIVE}

A number of factors are influencing insurers' views concerning capital adequacy in the current insurance industry environment. Overall, a shortage of capital is not a prob- lem for most insurers operating today; indeed, in the view of many, there is overcapacity in the industry. However, current conditions in the insurance industry may not prevail in the future. Overcapacity has intensified competition in the market for insurance products, driving a loosening in underwriting standards. While combined ratios-a measure of an insurer's overall underwriting profitability-are improving, this improvement largely reflects a lack of "catastrophes" and the resulting surge of claims, rather than strong underwriting practices. In many cases, loss reserves are not increasing commensurate with premium growth and profitability is being driven by attractive financial market returns, rather than by core underwriting activities. These conditions suggest that capital adequacy may become more of an issue in the not-too-distant future.

In March 1994, these views were nicely summarized by Alan M. Levin of Standard and Poor's:

Of course, a strong capital base is an important determinant, but without good business position and strategy, management acumen, liquidity and cash flow, favorable trends in key insurance markets, dependable reinsurance programs, and numerous other factors, a strong capital base can be rendered inadequate in an astonishingly short time.

As this quotation suggests, there are many sources of unexpected losses that can quickly erode an insurer's capital base. These include adverse claims development (as the result of one or more catastrophes or because general expectations of claims were understated); unrecognized concentrations of risk exposures in investments and credit extensions; unexpected market risk developments that adversely affect investment returns; and legal risks such as legislation requiring retroactive coverage of exposures.

Given these considerations and the general environment in the insurance industry today, AIG has developed a set of basic principles concerning our approach to capital adequacy and business strategy. To begin, capital must be sufficient to cover unexpected losses while maintaining AIG's credit rating. We feel that the credit rating, the best credit rating, is absolutely important for an insurance company to maintain soundness, to maintain credibility 
and confidence, and to be able to seek any opportunity that it finds profitable.

Further, the insurance business must return an underwriting profit, without consideration of returns from the investment portfolio, and underwriting decisions must be kept separate from investment decisions. We find "cashflow underwriting," as the term is called in the industry, to be a disturbing situation where risks are written assuming discount rates that require an insurer to take financial risk in order to achieve a profit. In a similar vein, operating cash flow and liquidity must be adequate to insulate the corporation from the need to liquidate investments to cover expected claims and losses. Finally, reserves must be built consistent with the company's current underwriting risk profile.

Our approach to modeling capital adequacy reflects these basic principles. First, we begin with actuarial assessments of capital and reserve adequacy for our underwriting business. We then look at balance-sheet capital, make economic adjustments, and allocate the adjusted capital to profit centers throughout the corporation. Each profit center must meet a hurdle rate of return without benefit of investment income. In this way, we assess capital adequacy in relation to the basic underwriting business, without relying on investment returns. To assess investment and other forms of credit risk, we are installing a credit risk costing model. Finally, we are in the process of implementing a market risk measurement model to assess market risks in our insurance-related investments as well as in our financial services businesses.

One important aspect of risk modeling that deserves special attention is concentration risk. Diversification of businesses is key to providing stable earnings, reserving, and capital growth. Ideally, capital modeling would be done using full covariance matrices to assess the degree of diversification-or, conversely, the degree of concentration-in business activities and other risks.
However, designing an approach that makes use of full covariance matrices is a complex undertaking. Instead, we plan to emphasize stress testing of correlation risks. In this way, we can assess the impact from adverse events on insurance, investment, liquidity, and financial services, and get a picture of the extent of concentration risk across our business activities.

In our firm, we try to stress test through scenarios that look at the correlation of insurance investments, market risks, and liquidity risks. For example, we might look at an eight-point Richter Scale earthquake in Tokyo, which our geologists tell us is a highly positively correlated event with a sizable earthquake in California. When we look at that scenario and at what could happen from an insurance company perspective, we look at the possibility that financial markets are disrupted or closed for a period of time. In this environment, companies have to react and respond, have the liquidity to be able to make the investment decisions, and not have to sell assets into a very disrupted market. At the same time, we want to have enough capital, and a strong enough credit rating, to be the corporation that we are today. These are the types of stress tests that we undertake, and judgment is a big component of the whole exercise.

\section{CONCLUSION}

This paper has provided a brief overview of the factors affecting capital adequacy in the insurance industry, both from the perspective of insurance regulators and an individual insurance company. The key idea is that we try to approach capital adequacy from the perspective of not only being able to play the game after adverse events have occurred, but being able to play the game the way we play it today. While risk modeling is an important part of this assessment, we use the modeling only with a very high degree of reason and discussion.

Thank you.

The views expressed in this article are those of the author and do not necessarily reflect the position of the Federal Reserve Bank of New York or the Federal Reserve System. The Federal Reserve Bank of New York provides no warranty, express or implied, as to the accuracy, timeliness, completeness, merchantability, or fitness for any particular purpose of any information contained in documents produced and provided by the Federal Reserve Bank of New York in any form or manner whatsoever. 